\title{
Using single or multiple liquor-donor cows for in vitro digestibility of amylase- and sodium sulfite-treated neutral detergent fiber with ash correction
}

\author{
A. Palmonari, ${ }^{1}$ G. Canestrari, M. Fustini, E. Bonfante, L. Mammi, and A. Formigoni \\ Department of Veterinary Medicine, Università di Bologna, 40064 Bologna, Italy
}

\begin{abstract}
In vitro methods requiring ruminal microorganisms to ferment and digest feeds have been used for decades. Though commonly accepted, collecting and pooling rumen fluid from different donor animals to avoid individual characteristics could affect in vitro fermentations. The current study evaluated the effects of individual or pooled liquors on in vitro digestibility of amylase- and sodium sulfite-treated NDF with ash correction (aNDFom). The study was conducted on 24 samples ( 8 alfalfa hays, 8 grass hays, and 8 corn silages). The 3 donor animals (treatment 1, 2, and 3) were selected based on similar body weights, parity, days in milk, milk production, and milk composition. Samples were digested in vitro via inoculation of different rumen fluid at different time points $(12,24,72$, and $120 \mathrm{~h}$ ). An equal amount of each liquor collected was sampled and equally mixed with the others to obtain treatment 4. For the alfalfa hay group, differences were observed at $12(29.95,27.07,29.02$, and $32.55 \%$ aNDFom for treatments $1,2,3$, and 4 , respectively) and $24 \mathrm{~h}(37.35$, $35.54,36.44$, and $40.56 \%$ aNDFom for treatments 1,2 , 3 , and 4 , respectively). The inoculum source did not affect in vitro digestibility over longer time periods (72 and $120 \mathrm{~h}$ ). Similar results were observed in the grass hay group, in which the mixed inoculum had greater digestibility values at both $12(28.86,26.89,27.88$, and $30.92 \%$ aNDFom for treatments $1,2,3$, and 4 , respectively) and $24 \mathrm{~h}(37.35,35.54,36.44$, and $40.56 \%$ aNDFom for treatment 1, 2, 3, and 4, respectively), but not over longer time periods. For the corn silage group, we observed differences for treatment 4 only at $12 \mathrm{~h}(35.78$, $33.87,34.83$, and $37.80 \%$ aNDFom for treatment $1,2,3$, and 4 , respectively). These results underline the differences among donor animals, especially when evaluating short incubation time points, and that pooling rumen
\end{abstract}

Received March 21, 2016.

Accepted August 27, 2016.

${ }^{1}$ Corresponding author: alberto.palmonari2@unibo.it contents is not equal to averaging across individual animals. Reported data require a deeper investigation on whether or not the method of inoculating a pool of rumen contents represents the actual ability of the animal to digest fiber.

Key words: rumen inoculum, in vitro fermentation, amylase-treated ash-corrected neutral detergent fiber with addition of sodium sulfite digestibility

\section{INTRODUCTION}

In vitro methods requiring rumen inoculum to ferment and digest feeds have been used for decades (Tilley and Terry, 1963; Goering and Van Soest 1970). In particular, in vitro digestibility of NDF (IVNDFD) can be correlated with animal performance (Allen and Oba, 1998) and used in rationing programs (Fox et al., 2004; Van Amburgh et al., 2015). The accuracy of these in vitro procedures is affected by different factors (Church and Petersen, 1960; Ayres, 1991), including the way samples are dried and ground (Wilman and Adesogan, 2000; Damiran et al., 2008). Others factors are related to the procedures (Uden et al., 1974; Marinucci et al., 1992; Holden, 1999) or to the dietary forage source of the rumen content-donor cow (Bezeau, 1965; Jung and Varel, 1988; Cherney et al., 1993; Soder, 2005).

Recently, a ring test has been conducted to evaluate the variability of in vitro digestibility techniques among different laboratories (Hall and Mertens, 2012); this study also reported the methods used by participating labs to evaluate digestibility. The majority of these laboratories collected and pooled rumen content from different cows, but there were differences in number of donor cows used, stage of lactation, and diet. Collecting rumen content from more than one donor cow is done frequently (Krizsan and Huhtanen, 2013; Palmonari et al., 2014, 2016), but, to our knowledge, no trials have been conducted to evaluate the effects of one or more donor cows on IVNDFD. The objective of the current study was to evaluate the possible effects of a single or mixed ruminal inoculum on IVNDFD of 3 different forage types. 


\section{MATERIALS AND METHODS}

The study was conducted at the University of Bologna and all procedures that included animals were approved by the University of Bologna Institutional Animal Care and Use Committee.

\section{Sample Description}

The alfalfa hay group (Medicago sativa, 8 different samples) was composed of different cuts (mostly second and third). Grass hay (8 unique samples) was mainly composed of different cool-season grasses; briefly, the pool of grass hay included wheat (Triticum aestivum), Italian ryegrass (Lolium multiflorum), and wild oats (Avena fatua). The corn silage group (Zea mays, 8 samples) was representative of some of the main hybrids commonly used for animal feedstuffs in Italy. Samples were treated as described in a previous paper (Palmonari et al., 2016). Briefly, forages were dried in a forcedair oven $\left(55^{\circ} \mathrm{C}\right)$ for $48 \mathrm{~h}$ and ground through a $1-\mathrm{mm}$ screen in a cyclone mill (model SM100, Retsch, Haan, Germany). The samples were analyzed for CP (AOAC 976.06, 984.13), amylase-treated ash-corrected NDF with addition of sodium sulfite (aNDFom; Mertens, 2002), ADF (AOAC, 1990; method 973.18), and ADL (AOAC, 1990; method 973.18), as described in a previous paper (Palmonari et al., 2016).

\section{Donor Cows and Rumen Fluid}

Three lactating Holstein cows were selected as donors based on similar BW, parity, DIM, milk production, and milk composition (SCC, fat and protein, lactose, and urea; Table 1). Animals were milked twice a day. Donor cows were fed a hay-based diet (Table 2) containing alfalfa hay (42\% aNDFom), grass hay $(48 \%$ aNDFom), and corn grain (62\% starch). Corn grain was ground with an industrial mill to obtain a final average meal size of $1.2 \mathrm{~mm}$. Rumen fluid was sampled via esophageal probe, pouring off the first volume collected to avoid saliva or mucous contamination, and immediately placed in a thermostatic bottle. Sampling was conducted $3 \mathrm{~h}$ after feeding. Rumen contents were filtered through 4 layers of cheesecloth under constant $\mathrm{O}_{2}$-free $\mathrm{CO}_{2}$. The 3 donor animals were designated as treatment 1, 2, and 3. Once filtered, an equal volume of each liquor collected was sampled and equally mixed with the others to obtain the fourth treatment.

\section{IVNDFD}

In vitro fermentations for NDF digestibility were performed at $12,24,72$, and $120 \mathrm{~h}$ using the Tilley
Table 1. Characteristics and production of rumen content donor cows

\begin{tabular}{lccc}
\hline & \multicolumn{3}{c}{ Treatment $^{1}$} \\
\cline { 2 - 4 } Measure & 1 & 2 & 3 \\
\hline BW, kg & 648 & 655 & 651 \\
Lactation number & 2 & 2 & 2 \\
DIM & 121 & 109 & 118 \\
Milk production, kg/d & 36.3 & 35.8 & 36.2 \\
Milk composition, \% & & & \\
Fat & 3.48 & 3.50 & 3.47 \\
Protein & 3.31 & 3.38 & 3.33 \\
Lactose & 5.02 & 4.96 & 4.85 \\
SCC, $\times 10^{3} / \mathrm{mL}$ & 137 & 148 & 145 \\
Urea, $\mathrm{mg} / 100 \mathrm{~mL}$ & 12.8 & 16.3 & 15.7 \\
\hline
\end{tabular}

${ }^{1}$ Treatments 1,2 , and 3 represent the individual donor animals.

and Terry modified technique (Tilley and Terry, 1963; Robertson and Van Soest, 1981), and according to the procedure described by Palmonari et al. (2016). Briefly, $10 \mathrm{~mL}$ of rumen fluid were added to each 150-mL Erlenmeyer flask that had been placed in a heated $\left(39.3^{\circ} \mathrm{C}\right)$ water bath under $\mathrm{CO}_{2}$-positive pressure to ensure anaerobiosis. Then $0.5 \mathrm{~g}$ of ground sample was weighed into each flask before the addition of $40 \mathrm{~mL}$ of buffer as described by Goering and Van Soest (1970). Each sample was digested in duplicate, in each of the 2 different in vitro incubations run, for a total of 4 replicates per sample. The 2 fermentations both started within $6 \mathrm{~d}$ of each other. For all analyses sample preparation was the same, as were the donor cows and their diet. At the end of the fermentation, contents of each flask were analyzed to determine NDF content of the residue and filtered through crucibles ( $40 \mu \mathrm{m}$ porosity) with the addition of microfiber glass filters $(1.5 \mu \mathrm{m}$, Whatman, GE Healthcare, Pittsburgh, PA). Residues were then treated following the procedure described by Goering and Van Soest (1970) after $3 \mathrm{~h}$ of drying in a forced-

Table 2. Composition of diet fed to rumen fluid donor cows

\begin{tabular}{lc}
\hline Diet composition & \% of diet DM \\
\hline Ingredient & \\
Grass hay & 25 \\
Alfalfa hay, 1st cut & 25 \\
Corn grain, finely ground & 25 \\
Barley grain, flaked & 10 \\
Soybean meal, 48\% CP & 10 \\
Cane molasses & 2.5 \\
Chemical composition & \\
aNDFom & \\
ADF & 33.1 \\
ADL & 21.5 \\
CP & 3.2 \\
Ether extract & 14.8 \\
Ash & 3.09 \\
Starch & 9.05 \\
\hline
\end{tabular}

$\overline{{ }^{1} \text { aNDFom }}=$ amylase- and sodium sulfite-treated NDF with ash correction. 
Table 3. Descriptive statistics (mean $\pm \mathrm{SE}$, minimum-maximum values) of chemical composition of the samples

\begin{tabular}{|c|c|c|c|}
\hline \multirow{2}{*}{$\begin{array}{l}\text { Chemical } \\
\text { composition, } \\
\% \text { of DM }\end{array}$} & \multicolumn{3}{|c|}{ Type of forage } \\
\hline & Grass hay, $\mathrm{n}=8$ & Alfalfa hay, $\mathrm{n}=8$ & Corn silage, $\mathrm{n}=8$ \\
\hline$\overline{\mathrm{CP}}$ & $11.9 \pm 0.27(3.6-15.9)$ & $17.8 \pm 0.27(8.4-24.2)$ & $7.7 \pm 0.11(4.4-12.6)$ \\
\hline aNDFom $^{1}$ & $55.3 \pm 0.54(40.1-75.7)$ & $44.1 \pm 0.66(32.9-52.9)$ & $47.3 \pm 0.32(34.5-54.2)$ \\
\hline $\mathrm{ADF}$ & $39.4 \pm 0.30(25.9-60.4)$ & $36.1 \pm 0.53(20.4-40.5)$ & $28.0 \pm 0.23(19.5-38.8)$ \\
\hline ADL & $7.3 \pm 0.12(4.8-13.4)$ & $8.8 \pm 0.15(5.8-15.7)$ & $3.8 \pm 0.05(2.1-6.7)$ \\
\hline
\end{tabular}

${ }^{1}$ aNDFom $=$ amylase- and sodium sulfite-treated NDF with ash correction.

air oven $\left(105^{\circ} \mathrm{C}\right)$; the hot weight of the crucibles was recorded. Ash correction was made after incineration of the residue at $495^{\circ} \mathrm{C}$ for $3 \mathrm{~h}$, followed by a second crucible hot weighing. Digestibility at any given time point was calculated as described in equation [1]:

$$
\begin{aligned}
& \text { IVNDFD, } \% \text { aNDFom }= \\
& {\left[1-\left(\mathrm{aNDFom}_{\mathrm{r}}-\mathrm{aNDFom}_{\mathrm{b}}\right) / \mathrm{aNDFom}_{\mathrm{i}}\right] \times 100,}
\end{aligned}
$$

where $\mathrm{aNDFom}_{\mathrm{r}}$ is the residual aNDFom, $\mathrm{aNDFom}_{\mathrm{b}}$ is the blank correction, and $\mathrm{aNDFom}_{\mathrm{i}}$ represents the initial NDF. All the described terms are expressed in grams.

For each treatment in both in vitro fermentations, lag time was evaluated using glass syringes. Briefly, a volume of $10 \mathrm{~mL}$ was obtained by inoculating $2 \mathrm{~mL}$ of each treatment to $8 \mathrm{~mL}$ of buffering solution, as described above; $0.1 \mathrm{~g}$ of each forage type was previously weighed in the syringes. Total gas production of the 24 syringes ( 8 syringes per forage type) was recorded every $30 \mathrm{~min}$ for $12 \mathrm{~h}$ to obtain the production curve. To calculate lag time, the one-pool exponential model of JMP-12 software (SAS Institute Inc., Cary, NC) was adopted.

\section{Statistical Analysis}

Statistical analysis was conducted via ANOVA using JMP-12 software (SAS Institute Inc.). The statistical model was based on lag time and digestibility data as dependent variables and treatment, fermentation, and their interaction as fixed variables. Because no significance was observed for the factor fermentation $(P=$ $0.91)$ or treatment $\times$ fermentation $(P=0.48)$, these variables were excluded from the model. Least squared means were compared using the Tukey adjustment, setting significance level at $P<0.01$. A contrast giving equal weights to the 3 individual samples versus the pooled sample was conducted to evaluate if averaging separate liquors equaled the result of pooling the liquors.

\section{RESULTS AND DISCUSSION}

Means and standard errors of the chemical composition of the samples are reported in Table 3. Evaluated lag times showed no differences among treatments for all the forage types $(P=0.78, P=0.87$, and $P=0.81$ for alfalfa hay, corn silage, and grass hay respectively). Average values of lag time were $3.35 \pm 0.2,3.28 \pm 0.1$, $3.31 \pm 0.2$, and $3.22 \pm 0.1 \mathrm{~h}$ for treatments $1,2,3$, and 4 , respectively. The lack of differences could represent evidence of a reduced internal variability of the fermentation procedures.

\section{Alfalfa Samples}

The in vitro estimation of NDF digestibility for alfalfa subsamples is reported in Table 4. Within the first time point, treatment 4 showed greater values compared with the other treatments $(P<0.01)$, with the exception of treatment $1(P=0.27)$, which resulted in no statistical differences with any other treatment. A similar situation was observed at $24 \mathrm{~h}$, for which treatment 4 showed higher results $(P<0.01)$. Digestibility obtained with the mixed inoculum was statistically different with treatment $2(P<0.01)$, whereas treatments 1 and 3 showed similarity to both treatments 4 and $2(P$ $>0.01)$. As the fermentation time increased, no differences among treatments were observed. Similar values were obtained at both 72 and $120 \mathrm{~h}$ of fermentation, even if values were numerically greater for treatment 4 compared with the others (Table 4).

\section{Corn Silage Samples}

Results obtained with the fermentations of corn silages were somewhat different than those for alfalfa and are reported in Table 4. Differences were observed at $12 \mathrm{~h}(P<0.01)$, whereas treatments resulted in no digestion differences for the remaining time points (Table 4). These results could be related to the intrinsic differences among forages, or more likely to the diets fed to the donor animals. Several studies reported the possible effects of diets fed on rumen inoculum compo- 
Table 4. Results of in vitro aNDFom digestibility of the 24 samples by different treatments

\begin{tabular}{|c|c|c|c|c|c|}
\hline \multirow[b]{2}{*}{ IVNDFD, ${ }^{1} \%$ of aNDFom } & \multicolumn{4}{|c|}{ Treatment $^{2}$} & \multirow[b]{2}{*}{ SEM } \\
\hline & 1 & 2 & 3 & 4 & \\
\hline \multicolumn{6}{|l|}{ Alfalfa hay, $\mathrm{n}=8$} \\
\hline $12 \mathrm{~h}$ & $29.95^{\mathrm{ab}}$ & $27.81^{\mathrm{b}}$ & $29.07^{\mathrm{b}}$ & $32.55^{\mathrm{a}}$ & 0.73 \\
\hline $24 \mathrm{~h}$ & $35.33^{\mathrm{ab}}$ & $32.92^{\mathrm{b}}$ & $34.25^{\mathrm{ab}}$ & $37.66^{\mathrm{a}}$ & 1.51 \\
\hline $72 \mathrm{~h}$ & 44.89 & 42.49 & 43.35 & 46.53 & 1.39 \\
\hline $120 \mathrm{~h}$ & 51.64 & 49.24 & 50.53 & 52.86 & 0.97 \\
\hline \multicolumn{6}{|l|}{ Corn silage, $\mathrm{n}=8$} \\
\hline $12 \mathrm{~h}$ & $35.78^{\mathrm{b}}$ & $33.87^{\mathrm{c}}$ & $34.83^{\mathrm{bc}}$ & $37.80^{\mathrm{a}}$ & 0.30 \\
\hline $24 \mathrm{~h}$ & 42.56 & 39.95 & 41.26 & 45.18 & 1.38 \\
\hline $72 \mathrm{~h}$ & 64.15 & 62.19 & 63.17 & 65.60 & 2.13 \\
\hline $120 \mathrm{~h}$ & 67.96 & 66.38 & 67.17 & 68.74 & 1.64 \\
\hline \multicolumn{6}{|l|}{ Grass hay, $\mathrm{n}=8$} \\
\hline $12 \mathrm{~h}$ & $28.86^{\mathrm{b}}$ & $26.78^{\mathrm{c}}$ & $27.88^{\mathrm{bc}}$ & $30.32^{\mathrm{a}}$ & 0.28 \\
\hline $24 \mathrm{~h}$ & $37.35^{\mathrm{ab}}$ & $35.54^{\mathrm{b}}$ & $36.44^{\mathrm{b}}$ & $40.56^{\mathrm{a}}$ & 1.44 \\
\hline $72 \mathrm{~h}$ & 57.34 & 55.18 & 56.26 & 58.89 & 1.13 \\
\hline $120 \mathrm{~h}$ & 64.88 & 62.79 & 63.83 & 65.92 & 2.19 \\
\hline
\end{tabular}

$\overline{\mathrm{a}, \mathrm{b}}$ Means in a row with different superscripts differ $(P<0.01)$.

${ }^{1}$ IVNDFD $=$ in vitro NDF digestibility, in percent of aNDFom (amylase- and sodium sulfite-treated NDF with ash correction).

${ }^{2}$ Treatments 1, 2, and 3 represent the individual donor animals, whereas 4 is the pool of the individual rumen contents.

sition (Bezeau, 1965; Grant et al., 1974; Soder, 2005). In the current study, donor animals were fed a dry haybased diet not including any corn silage sources, yet did include corn grain.

\section{Grass Hay Samples}

Grass hay samples gave results similarly to the alfalfa set (Table 4). The in vitro digestibility at 12 and 24 $\mathrm{h}$ was greater for treatment 4 . In particular, at $12 \mathrm{~h}$ of fermentation, treatment 4 was different to all other treatments $(P<0.01)$, whereas at $24 \mathrm{~h}$ treatment 1 showed greater results $(P<0.01)$ compared with treatments 2 and 3. As observed for alfalfa hay and corn silage, even grass hay showed no differences in digestibility at 72 or $120 \mathrm{~h}$.

\section{Individual Versus Pooled Rumen Content}

Contrast analysis showed differences $(P<0.01)$ for all samples at $12 \mathrm{~h}$ (Table 5). A similar situation was observed at $24 \mathrm{~h}$, with the exception of the corn silage group, which had no significance among the averaged individual inoculum and treatment 4 . These results suggested that pooling rumen content allow to obtain digestibility results greater than those observed for each individual inoculum. It is possible to hypothesize that mixing rumen content could lead to a sort of synergy between the different bacterial consortia, which resulted in an increased fiber digestibility.

The relationship among the rumen bacterial community and animal is strictly individual (Palmonari et al., 2010; Weimer et al., 2010a,b), and could carry differences even under similar conditions of animal health or ruminal temperature or $\mathrm{pH}$. Weimer et al. (2010a) reported the ability of the animal to drive and modify its rumen bacterial community even after a near-total exchange of rumen content with another animal, demonstrating this tight relationship. In the current study, this ability of the cow to control its rumen microflora could be the main factor accounting for the observed differences among treatments at short fermentation time points. Recorded data showed no difference as fermentation time increased, suggesting an important effect of the environmental conditions of the in vitro procedure on the microorganisms. In vitro conditions, even if very well standardized and designed to mimic

Table 5. Contrast analysis between averaged treatments 1,2 , and 3 against $4^{1}$

\begin{tabular}{lccc}
\hline IVNDFD $^{2}$ & $\begin{array}{c}\text { Estimated } \\
\text { difference }\end{array}$ & $\mathrm{SE}$ & $P$-value \\
\hline Alfalfa hay & & & \\
$12 \mathrm{~h}$ & -3.31 & 0.43 & 0.004 \\
$24 \mathrm{~h}$ & -3.28 & 1.32 & 0.031 \\
Corn silage & & & \\
$12 \mathrm{~h}$ & -2.84 & 0.75 & 0.008 \\
$24 \mathrm{~h}$ & -3.76 & 1.18 & 0.23 \\
Grass hay & & & \\
$12 \mathrm{~h}$ & -2.27 & 0.66 & 0.006 \\
$24 \mathrm{~h}$ & -3.94 & 1.41 & 0.043 \\
\hline
\end{tabular}

${ }^{1}$ IVNDFD $=$ in vitro NDF digestibility, in percent of aNDFom (amylase- and sodium sulfite-treated NDF with ash correction).

${ }^{2}$ Treatments 1, 2, and 3 represent the individual donor animals, whereas 4 is the pool of the individual rumen contents. 
the rumen environment, are substantially different from the rumen itself, and some bacterial populations are probably more able than others to adapt to this environment.

\section{CONCLUSIONS}

Data obtained in the current study underline that different results of in vitro aNDFom digestibility are found if rumen contents are collected from different animals. Also, results from the pooled liquor are not the same as those from averaging across individuals. In both cases, differences were greater for shorter fermentation periods. Source of inoculum was also more effective on grass and alfalfa hays compared with corn silage. Thus, reported data require deeper investigation as to whether the method of inoculating a pool of rumen contents represents the actual ability of the animal to digest fiber. Future studies are highly recommended to identify and evaluate these differences on a microbiological perspective.

\section{REFERENCES}

Allen, M. S., and M. Oba. 1998. Digestibility of forage fiber-Variation, measurements, and relationship to animal performance. Pages 125-138 in Proc. Western Canadian Dairy Seminar, Advances in Dairy Technology. Univ. Alberta, Edmonton, Canada.

AOAC. 1990. Official Methods of Analysis. 15th ed. AOAC, Arlington, VA.

Ayres, J. F. 1991. Sources of error with in vitro digestibility assay of pasture feeds. Grass Forage Sci. 46:89-97.

Bezeau, L. M. 1965. Effect of source of inoculum on digestibility of substrate in in vitro digestion trials. J. Anim. Sci. 65:823-825.

Cherney, D. J. R., J. Siciliano-Jones, and A. N. Pell. 1993. Technical note: Forage in vitro dry matter digestibility as influenced by fiber source in the donor cow diet. J. Anim. Sci. 71:1335-1338.

Church, D. C., and R. G. Petersen. 1960. Effect of several variables on in vitro rumen fermentation. J. Dairy Sci. 43:81-92.

Damiran, D., T. Del Carlo, D. W. Bohnert, and S. L. Findholt. 2008 Comparison of techniques and grinding size to estimate digestibility of forage based ruminant diets. Anim. Feed Sci. Technol. 141:15-35.

Fox, D. G., L. O. Tedeschi, T. P. Tylutki, J. B. Russell, M. E. Van Amburgh, L. E. Chase, A. N. Pell, and T. R. Overton. 2004. The Cornell Net Carbohydrate and Protein System model for evaluating herd nutrition and nutrient excretion. Anim. Feed Sci. Technol. 112:29-78.

Goering, H. K., and P. J. Van Soest. 1970. Forage Fiber Analysis (Apparatus, Reagents, Procedures, and Some Applications). Agricultural Handbook No. 379. USDA-Agricultural Research Service, Washington, DC.

Grant, R. J., P. J. Van Soest, and R. E. McDowell. 1974. Influence of rumen fluid source and fermentation time on in vitro true dry matter digestibility. J. Dairy Sci. 57:1201-1205.
Hall, M. B., and D. R. Mertens. 2012. A ring test of in vitro neutral detergent fiber digestibility: Analytical variability and sample ranking. 2012. J. Dairy Sci. 95:1992-2003. http://dx.doi.org/10.3168/ jds.2011-4802.

Holden, L. A. 1999. Comparison of methods of in vitro dry matter digestibility for ten feeds. J. Dairy Sci. 82:1791-1794. http://dx.doi. org/10.3168/jds.S0022-0302(99)75409-3.

Jung, H. G., and V. H. Varel. 1988. Influence of forage type on ruminal bacterial populations and subsequent in vitro fiber digestion. J. Dairy Sci. 71:1526-1535.

Krizsan, S. J., and P. Huhtanen. 2013. Effect of diet composition and incubation time on feed indigestible neutral detergent fiber concentration in dairy cows. J. Dairy Sci. 96:1715-1726.

Marinucci, M. T., B. A. Dehority, and S. C. Loerch. 1992. In vitro and in vivo studies of factors affecting digestion of feeds in synthetic fiber bags. J. Anim. Sci. 70:296-307.

Mertens, D. R. 2002. Gravimetric determination of amylase-treated neutral detergent fiber in feeds with refluxing in beakers or crucibles: collaborative study. J. AOAC Int. 85:1217-1240.

Palmonari, A., M. Fustini, G. Canestrari, E. Grilli, and A. Formigoni. 2014. Influence of maturity on alfalfa hay nutritional fractions and indigestible fiber content. J. Dairy Sci. 97:7729-7734. http:// dx.doi.org/10.3168/jds.2014-8123.

Palmonari, A., A. Gallo, M. Fustini, G. Canestrari, F. Masoero, C. J. Sniffen, and A. Formigoni. 2016. Estimation of the indigestible fiber in different forage types. J. Anim. Sci. 94:248-254. http:// dx.doi.org/10.2527/jas.2015-9649.

Palmonari, A., D. M. Stevenson, D. R. Mertens, C. W. Cruywagen, and P. J. Weimer. 2010. pH dynamics and bacterial community composition in the rumen of lactating dairy cows. J. Dairy Sci. 93:279-287. http://dx.doi.org/10.3168/jds.2009-2207.

Robertson, J. B., and P. J. Van Soest. 1981. The detergent system of analysis and its application to human foods. Pages 123-158 in The Analysis of Dietary Fiber in Foods. W. P. T. James and O. Theander, ed. Marcel Dekker, New York. NY.

Soder, K. J. 2005. Technical note: Influence of rumen inoculum source on in vitro dry matter digestibility of pastures. Prof. Anim. Sci. 21:45-49.

Tilley, J. M. A., and R. A. Terry. 1963. A two-stage technique for the in vitro digestion of forage crops. J. Br. Grassl. Soc. 18:104-111. http://dx.doi.org/10.1111/j.1365-2494.1963.tb00335.

Uden, P., R. Parra, and P. J. Van Soest. 1974. Factors influencing reliability of the nylon bag technique. J. Dairy Sci. 57:622.

Van Amburgh, M. E., E. A. Collao-Saenz, R. J. Higgs, D. A. Ross, E. B. Recktenwald, E. Raffrenato, L. E. Chase, T. R. Overton, J. K. Mills, and A. Foskolos. 2015. The Cornell Net Carbohydrate and Protein System: Updates to the model and evaluation of version 6.5. J. Dairy Sci. 98:6361-6380. http://dx.doi.org/10.3168/ jds.2015-9378

Weimer, P. J., D. M. Stevenson, H. C. Mantovani, and S. L. C. Man 2010a. Host specificity of the ruminal bacterial community of the dairy cow following a near-total exchange of ruminal contents. J. Dairy Sci. 93:5902-5912. http://dx.doi.org/10.3168/jds.2010-3500.

Weimer, P. J., D. M. Stevenson, and D. R. Mertens. 2010b. Shifts in bacterial community composition in the rumen of lactating dairy cows under conditions of milk fat depression. J. Dairy Sci. 93:265278. http://dx.doi.org/10.3168/jds.2009-2206.

Wilman, D., and A. Adesogan. 2000. A comparison of filter bag methods with conventional tube methods of determining the in vitro digestibility of forages. Anim. Feed Sci. Technol. 84:33-47. 